\title{
Improving in vitro induction of autopolyploidy in grapevine seedless cultivars
}

\author{
Iraci Sinski • Daniela Dal Bosco • \\ Neiva Izabel Pierozzi · João Dimas Garcia Maia • \\ Patrícia Silva Ritschel · Vera Quecini
}

Received: 18 August 2013/ Accepted: 19 November 2013

(C) Springer Science+Business Media Dordrecht 2013

\begin{abstract}
The efficiency of in vitro polyploidization depends on several variables associated to the plant, the antimicrotubule agent and the interactions between them. In the present work, we have used responsesurface methodology to determine the best operating conditions for plant recovery in polyploidization assays for shoot apices and somatic embryos of two seedless grape cultivars, employing colchicine and oryzalin. Explant type, tubulin-interfering compound and concentration were the critical factors determining plant recovery. Linear reduction in viable plant regeneration via organogenesis and somatic embryogenesis was obtained by increasing oryzalin concentrations and treatment time, whereas the effects of
\end{abstract}

Electronic supplementary material The online version of this article (doi:10.1007/s10681-013-1034-8) contains supplementary material, which is available to authorized users.

I. Sinski · D. Dal Bosco · P. S. Ritschel · V. Quecini ( $\square)$ Embrapa Uva e Vinho (Brazilian Agricultural Research Corporation - Grapevine and Wine Research Center), Rua Livramento, 515, Caixa Postal 130, Bento Gonçalves, RS 95700-000, Brazil

e-mail: vera.quecini@embrapa.br

N. I. Pierozzi

Genetic Resources Center, Instituto Agronômico de Campinas, Caixa Postal 28, Campinas, SP 13001-970, Brazil

J. D. G. Maia

Tropical Viticulture Experimental Station, Embrapa Uva e

Vinho, Caixa Postal 241, Jales, SP 15700-000, Brazil colchicine were better described by a quadratic design for both explants types. The conditions promoting higher rates of plant recovery were used in chromosome doubling experiments with oryzalin and colchicine for shoot apices and somatic embryos of 'Crimson seedless' and 'BRS Clara'. The established protocols allowed the recovery of non-chimerical autotetraploid plants at rates higher than $30 \%$ for both cultivars. Stomata size parameters statistically correlate to the ploidy level of the regenerants and were effective for preliminary polyploidy screening. Autotetraploid lines of seedless grapes were incorporated into the Vitis germplasm bank for further agronomical evaluations. To our knowledge, this is the first report of in vitro oryzalin induced polyploidization of grapevine and of the use of mathematical modeling to optimize chromosome doubling in plants.

Keywords Colchicine - Organogenesis · Oryzalin $\cdot$ Polyploidy $\cdot$ Seedless grape $\cdot$ Somatic embryogenesis

\section{Introduction}

Worldwide there is a growing demand for quality seedless grapes, which drives breeding programs to develop novel cultivars exhibiting the trait. Seedlessness in grapevine is mainly due to stenospermocarpy, a genetically controlled arrest of embryo development after fertilization (Bergamini et al. 2013; Stout 1936). 
Impaired embryo development in stenospermocarpic grapes reduces hormone biosynthesis and signaling leading to reduced berry growth and interfering with ripening (López-Miranda et al. 2011; Nitsch et al. 1960; Sweetman et al. 2012). Thus, several cultural practices and exogenous growth regulators applications are required for seedless berries to achieve the desired sensorial features, including size, color and cluster aspect (Dokoozlian et al. 1995). These practices greatly increase production costs and exogenous application of plant growth regulators may lead to severe hormonal imbalance in other plant organs or neighboring plants due to pleiotropic effects, as well as raise safety environmental and consumers concerns (Arora et al. 2009; Sharma and Awasthi 2003; Xue et al. 2011).

Since the 1910s, grapevine plants with spontaneous alterations in somatic cell ploidy have been selected and vegetatively propagated to give rise to homogeneous polyploids due to their vigorous growth habit and larger berries (Olmo 1952). Most recently, whole genome studies have demonstrated the role of polyploidy in increasing plant phenotypic plasticity in adaptation traits, such as water stress tolerance, flowering time and organ size (Doyle et al. 2008; Chen 2010).

In vitro treatment of plant material with polyploidyinducing agents provides higher rates of chromosome doubling in wide range of species (Yang et al. 2006; Cai and Kang 2011; Dhooghe et al. 2011). Several compounds interfere with cell cycle progression, mainly by affecting polymerization and depolymerization of tubulin, the main component of microtubules that constitute the mitotic spindle apparatus, and have been used to artificially induce chromosome duplication in plants (Kasha 2005; Dhooghe et al. 2011). The most widely used polyploidization compound in plants is colchicine, an alkaloid isolated from Colchicum autumnale, that binds tubulin impairing its polymerization or, at high concentrations, promoting microtubule depolymerization (Caperta et al. 2006). Recently, novel compounds, such as herbicides from the dinitroaniline and benzamide classes (trifluralin, oryzalin and pronamide), atoxic alkaloids (caffeine) and benzofurans (griseofulvin), with higher affinity for plant tubulins and less toxic to mammals are being used (Häntzschel and Weber 2010). Currently, there are no reports on the effects of oryzalin in chromosome doubling in Vitis species, since colchicine has been the solely agent tested (Dhooghe et al. 2011; Notsuka et al. 2000; Yang et al. 2006).

In the current work, we have employed mathematical modeling by response surface methodology to improve plant recovery after colchicine and oryzalin treatment for in vitro alteration of grapevine chromosome number, using two distinct regeneration systems; multibrotation of shoot apices and somatic embryogenesis. The developed protocols were effective to produce autopolyploid plants in two important seedless grape cultivars; 'Crimson seedless' and 'BRS Clara' at high frequencies.

\section{Material and methods}

\section{Plant material}

Two diploid seedless grapevine (Vitis sp.) cultivars $(2 n=2 \mathrm{x}=38)$ were employed in chromosome doubling experiments; 'Crimson seedless' and 'BRS Clara'. 'Crimson seedless' is an important commercial variety of table grape, developed by the Agriculture Research Service of the United States Department of Agriculture (ARS/USDA, Fresno, California) (Ramming et al. 1995) and 'BRS Clara', developed by the grapevine breeding program at Embrapa, is a highly productive cultivar adapted to tropical and subtropical conditions (Camargo et al. 2003). Shoots and immature flowers for explanting were obtained from greenhouse cultivated branch segments (approximately $20 \mathrm{~cm}$ in length, with three to four lateral meristems), grown at $25 \pm 3{ }^{\circ} \mathrm{C}$, natural light and $70 \%$ relative humidity, in $2 \mathrm{~L}$ plastic bags containing a 1:1:1 mixture of autoclaved soil: horticulture substrate: vermiculite.

\section{Shoot apices}

Young shoots from greenhouse cultivated stakes were excised and the leaves, removed. Subsequently, explants were surface disinfected in $70 \%(\mathrm{v} / \mathrm{v})$ ethanol for $60 \mathrm{~s}$, followed by immersion in $1.0 \%(\mathrm{v} / \mathrm{v})$ sodium hypochloride supplemented with $0.02 \%(\mathrm{v} / \mathrm{v}) \mu \mathrm{L}$ of Tween 20 for $20 \mathrm{~min}$, and five washes with excess of autoclaved distilled water. Individual stem segments containing a single lateral meristem were inoculated basipetally in test tubes containing $15 \mathrm{~mL}$ of Galzy medium (Galzy 1964) supplemented with $2.5 \%$ (w/v) of activated charcoal and cultivated under $16 \mathrm{~h}$ photoperiod, provided by 
$75 \mathrm{mmol} \mathrm{m} \mathrm{m}^{-2} \mathrm{~s}^{-1}$ white LED sources and $23 \pm 2{ }^{\circ} \mathrm{C}$. Rooted plantlets were propagated to Galzy medium and shoot apices were dissected, under stereomicroscope in aseptic conditions, from four-week old plants to produce the explants for polyploidy-inducing experiments.

\section{Somatic embryogenesis}

Immature flowers were detached from the clusters and surface disinfected as described previously for the shoot explants. Whole flowers were dissected under stereomicroscope in aseptic conditions and inoculated, with the peduncle side down, on somatic embryogenesis induction medium PIV (Franks et al. 1998; Gribaudo et al. 2004). Explants were transferred to fresh medium at four to six weeks intervals. Approximately eight weeks after inoculation, embryogenic calli were transferred to embryo proliferation medium GS1CA (Franks et al. 1998). Cotyledonary stage embryos were detached from calli and employed for antimitotic agent treatment.

Treatment with antimitotic agents colchicine and oryzalin

Somatic embryos and shoot apices were submitted to five independent factorial experiments with antimitotic agent, consisting of the following concentrations: 0,20 , 100,250 and 1,250 $\mu \mathrm{M}$ for colchicine and 0, 20, 40, 60 and $80 \mu \mathrm{M}$ for oryzalin, combined with $0,12,24,36$ and $48 \mathrm{~h}$ incubation times, in the dark at $18 \pm 2{ }^{\circ} \mathrm{C}$, with shaking at $75 \mathrm{rpm}$. Shoot apices were incubated in liquid C2D4B medium (Dutt et al. 2008) and somatic embryos, in liquid GS1CA (Franks et al. 1998) supplemented with the tested concentrations of the antimitotic agents. Five replicates consisting of approximately 20 explants were used per individual experiment. After the treatment, the explants were thoroughly washed with fresh liquid medium and transferred to Petri dishes containing C2D4B or GS1CA media solidified with $7 \%$ (w/v) agar for shoot apices or somatic embryos, respectively. Regenerants were individualized and transferred to tubes containing Galzy medium for rooting and subsequent ploidy analyses.

\section{Ploidy determination}

The ploidy level of the regenerants was initially investigated by morphological analysis of mesophyll epidermal structures under light microscopy. Five independent microscopic fields were digitally photographed at $400 \times$ magnification and analyzed for stomata density, guard cell length and width using ImageJ (Schneider et al. 2012).

Root tips were excised from in vitro plants, overnight incubated in $0.01 \%(\mathrm{w} / \mathrm{v})$ colchicine at $18{ }^{\circ} \mathrm{C}$ and fixed with $1: 3$ acetic acid: ethanol for one week at room temperature. Fixed roots were treated with an enzyme mixture, consisting of $2 \%(\mathrm{w} / \mathrm{v})$ cellulase and $2 \%(\mathrm{w} / \mathrm{v})$ pectinase, for $1 \mathrm{~h}$ at room temperature and squashed with a cover slip in $45 \%$ acetic carmine prior to microscopic analysis at $1,000 \times$ magnification. Five microscopic fields from three independent root tips were digitally photographed for chromosome counting. Representative metaphasic cell nuclei are shown.

Data analysis

The experiments were carried out in a factorial design, consisting of two qualitative variables: cultivars and explants type, combined with two quantitative ones: antimitotic agents colchicine (range $0-1,250 \mu \mathrm{M}$ ) and oryzalin (range $0-80 \mu \mathrm{M}$ ) and treatment times (range 0-48 h). Three independent experiments with 20 explants per treatment were performed. The statistical significance was analyzed by ANOVA and mean comparison tests ( $t$ test and Tukey's Honestly Significant Difference-HSD). Response surface methodology (RSM) was based on a five-level two variable Central Composite Design (CCD) employing the RSM package (Lenth 2009) of the R software (R Core Team 2012). Mathematical and statistical techniques are used in RSM to determine the functional relationship between a response of interest and a number of associated variables through experimental methods (Lenth 2009). Different levels of the operating conditions comprise the experimental factors that may be categorical (qualitative) or quantitative. The used design (CCD) is an experimental design used in RSM to build a second order (quadratic) model for the response variable without the need of a complete three-level factorial experiment. It is possible due to sequential augmentation of experimental blocks when higher order fitting is needed. The canonical analysis of second order response surfaces can be represented as contour plots, in which the contour lines, representing the levels of the response, are overlaid on heat 
maps that indicate direction of the response as a function of the investigated variables.

\section{Results}

Effect of the cultivar and explants type

Initially, we have surveyed the effects of the categorical variables (explants type and cultivar) on plant recovery after antimitotic agent treatment. The statistical significance of the tested factors is summarized in Table S1. Effective regeneration via shoot apices organogenesis (SAM) and somatic embryogenesis (SE) was obtained for 'BRS Clara' and 'Crimson Seedless' (Fig. 1). The average number of recovered plants was not significantly different between the cultivars for regeneration via SE $(4.17 \pm 4.33$ and $4.22 \pm 5.89$, respectively) and SAM (11.55 \pm 10.04
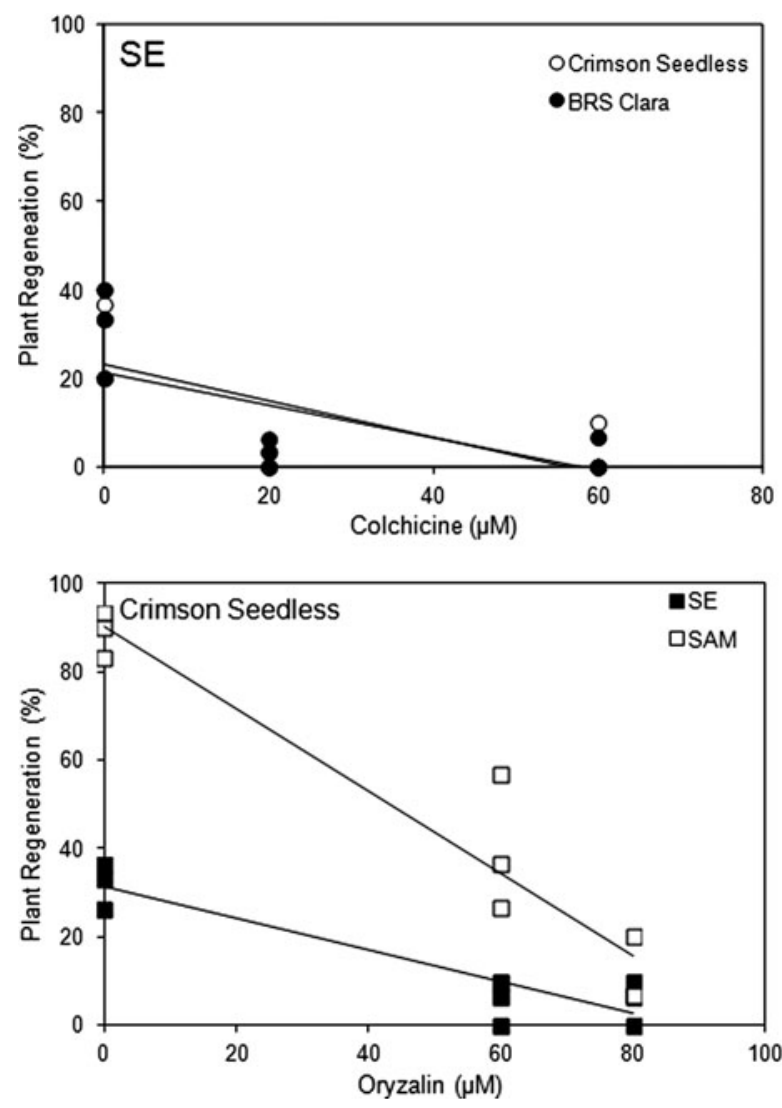

Fig. 1 Effect of antimicrotubule agent treatment on plant regeneration from shoot apices (SAM) and somatic embryos (SE) of seedless grape cultivars 'BRS Clara' and 'Crimson and $9.56 \pm 9.04$, respectively), by Tukey HSD test. In contrast, the regeneration system had a significant impact on plant recovery for both tested cultivars; higher rates of shoot formation were achieved by organogenesis induction of shoot apices (Figs. 1, 2).

Effect of the antimitotic agent and treatment time on plant regeneration

The combined effects of antimitotic agents, their concentration and treatment time on SE and SAM regeneration systems were analyzed by the responsesurface methodology (RSM). The cultivar effect was not statistically significant (Fig. 2; Tables S1, S2), thus, data from 'BRS Clara' and 'Crimson Seedless' were pooled for RSM analyses. Colchicine concentrations and treatment time were based on previous reports by Notsuka et al. (2000) and Yang et al. (2006). The use of oryzalin for chromosome doubling has not
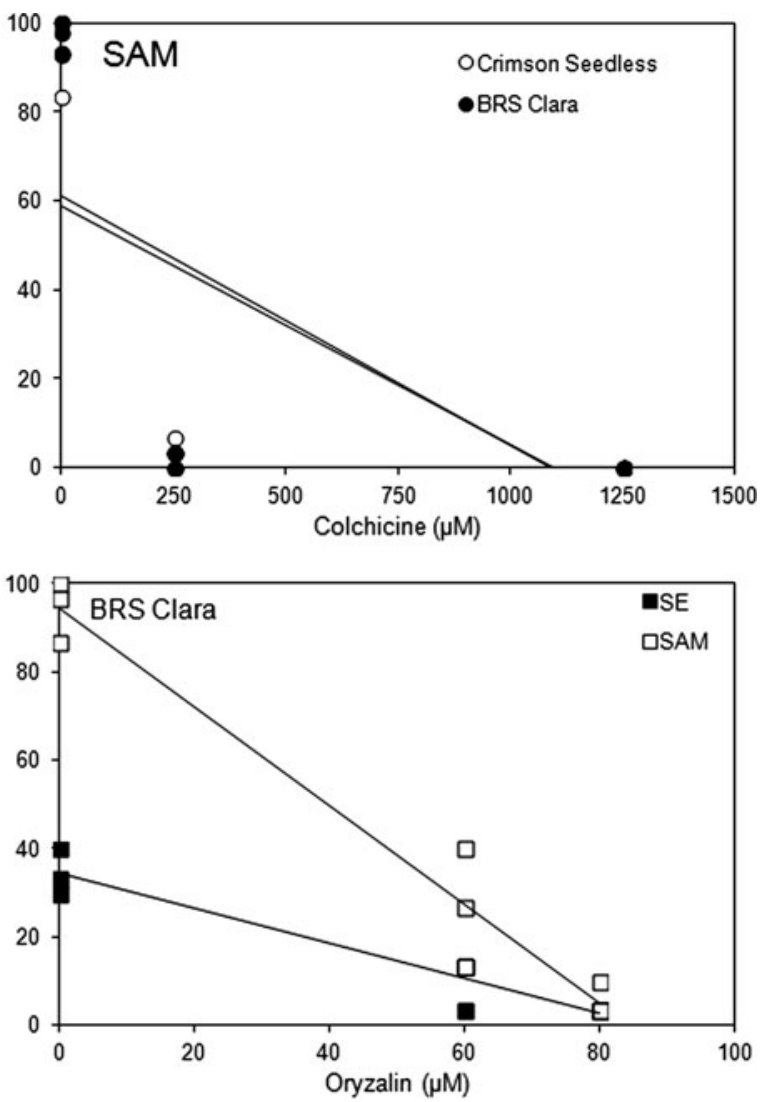

Seedless'. Vertically aligned data correspond to 0,24 and $48 \mathrm{~h}$ treatment duration from three independent experiments, each consisting of 60 explants 

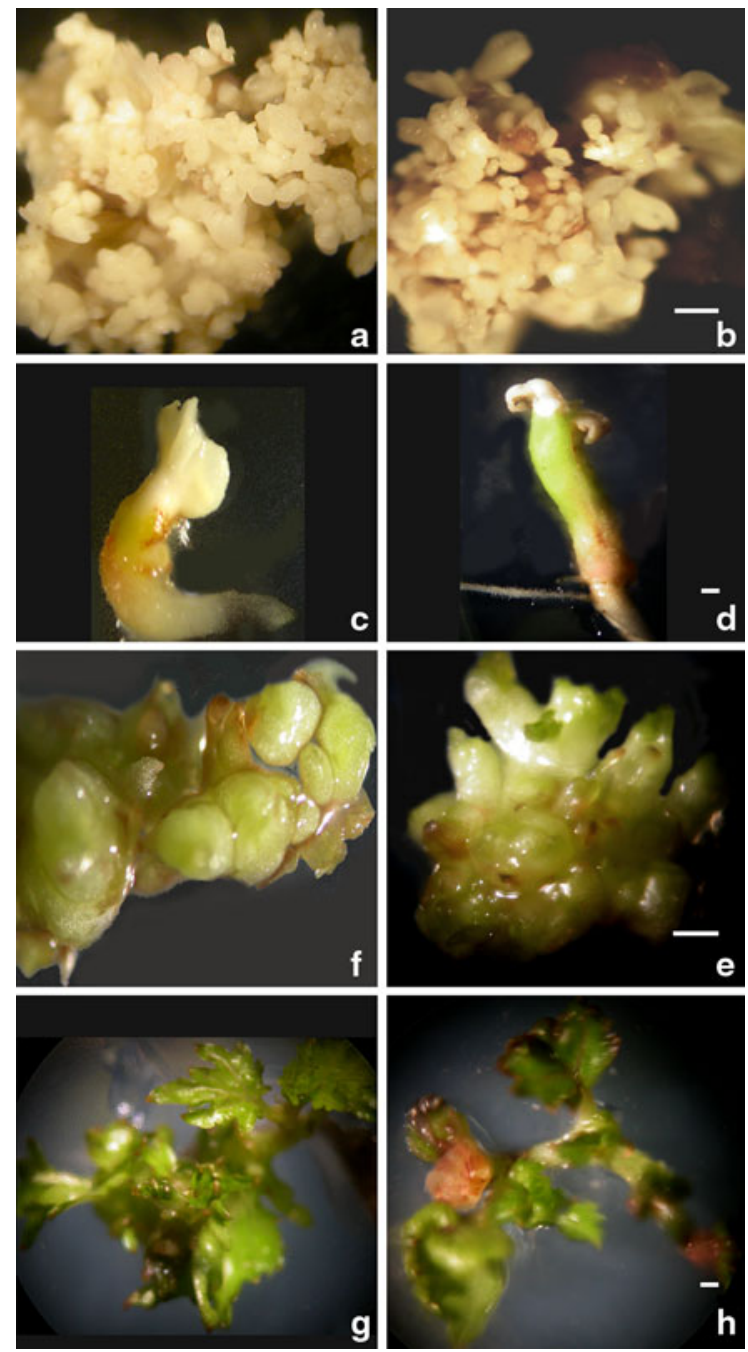

Fig. 2 In vitro plant regeneration via somatic embryogenesis and organogenesis from shoot apices of 'BRS Clara' (a, c, e, g) and 'Crimson Seedless' (b, d, f, h). a, b Embryogenic calli (bar $0.5 \mathrm{~mm}$ ). c, d Somatic embryo germination (bar $0.5 \mathrm{~mm}$ ). $\mathbf{e}, \mathbf{f}$ Apices multibrotation (bar $0.5 \mathrm{~mm}$ ). $\mathbf{g}$, h Plant regeneration (bar $0.2 \mathrm{~mm})$. Magnification $\times 60(\mathbf{a}, \mathbf{b}, \mathbf{c}, \mathbf{d}, \mathbf{e}, \mathbf{f})$ and $\times 10(\mathbf{g}, \mathbf{h})$

been previously reported for grapevine, so we have tested the concentrations and incubation times commonly employed for polyploidization in plants (review in (Dhooghe et al. 2011)).

Treatment with colchicine and oryzalin had a drastic negative effect on plant recovery by SE and SAM, even at lower concentrations and shorter exposure times (Figs. 3, 4; Table S2). Colchicine effects were best described by a second order (quadratic) design with response maxima ranging from 720 to $760 \mu \mathrm{M}$ of colchicine, for SE and SAM, throughout the treatment duration (Fig. 4; Table S2). The estimated stationary points for colchicine concentration and treatment time for SE and SAM are within the experimental values, suggesting that the response surface is a precise representation of the biological phenomenon (Table S2). The negative eigenvalues also indicate that the stationary points are close to the design center and the operation conditions are near optimum for plant regeneration (Table S2). A 200 re-fit bootstrap analysis of the experiment residuals also demonstrate the accuracy of the stationary points estimation (Fig. S1).

In contrast, the best model describing the plant regeneration response to oryzalin is a first order (linear) design, with the steepest ascent corresponding to increments of $-19.18 \mu \mathrm{M}$ oryzalin for SE, and $-17.78 \mu \mathrm{M}$ for SAM and (Fig. 4; Table S2). Thus, the reduction in plant regeneration is linearly correlated to oryzalin concentration and exposure time, and the direction of the steepest ascent indicates that increasing oryzalin concentrations has greater effect on plant regeneration than extending treatment time (Fig. 4; Table S2).

In vitro induction of autopolyploidy in 'Crimson Seedless' and 'BRS Clara'

The conditions allowing higher rates of plant regeneration from SE and SAM under colchicine and oryzalin treatments were employed for in vitro chromosome doubling. A total of 59 regenerants were analyzed from colchicine treatments, from which 22 $(37.30 \%)$ were confirmed to be polyploids $(4 n=78)$ (Table 1). The efficiencies of colchicine treatments for somatic embryo polyploidization of 'BRS Clara' were of $33.33 \%$ and $41.67 \%$ for 'Crimson seedless'. Diploid and aneuploid regenerants were recovered at frequencies of $47.45 \%$ and $10.17 \%$, respectively, whereas mixoploids and visually identifiable mutants, such as common albino, crème and fusca phenotypes (Jürgens et al. 1991; Berenschot et al. 2008), were not obtained (Table 1).

Sixty-eight $(54.40 \%)$ plants resulting from oryzalin treatment were submitted to cytological analyses, allowing the identification of $39(57.35 \%)$ tetraploids (Table 2). The frequencies of diploids (45.58\%) and aneuploids $(2.94 \%)$ were lower than those found for colchicine treatment (Tables 1, 2). As inferred by RSM modeling, oryzalin is less damaging to grapevine 


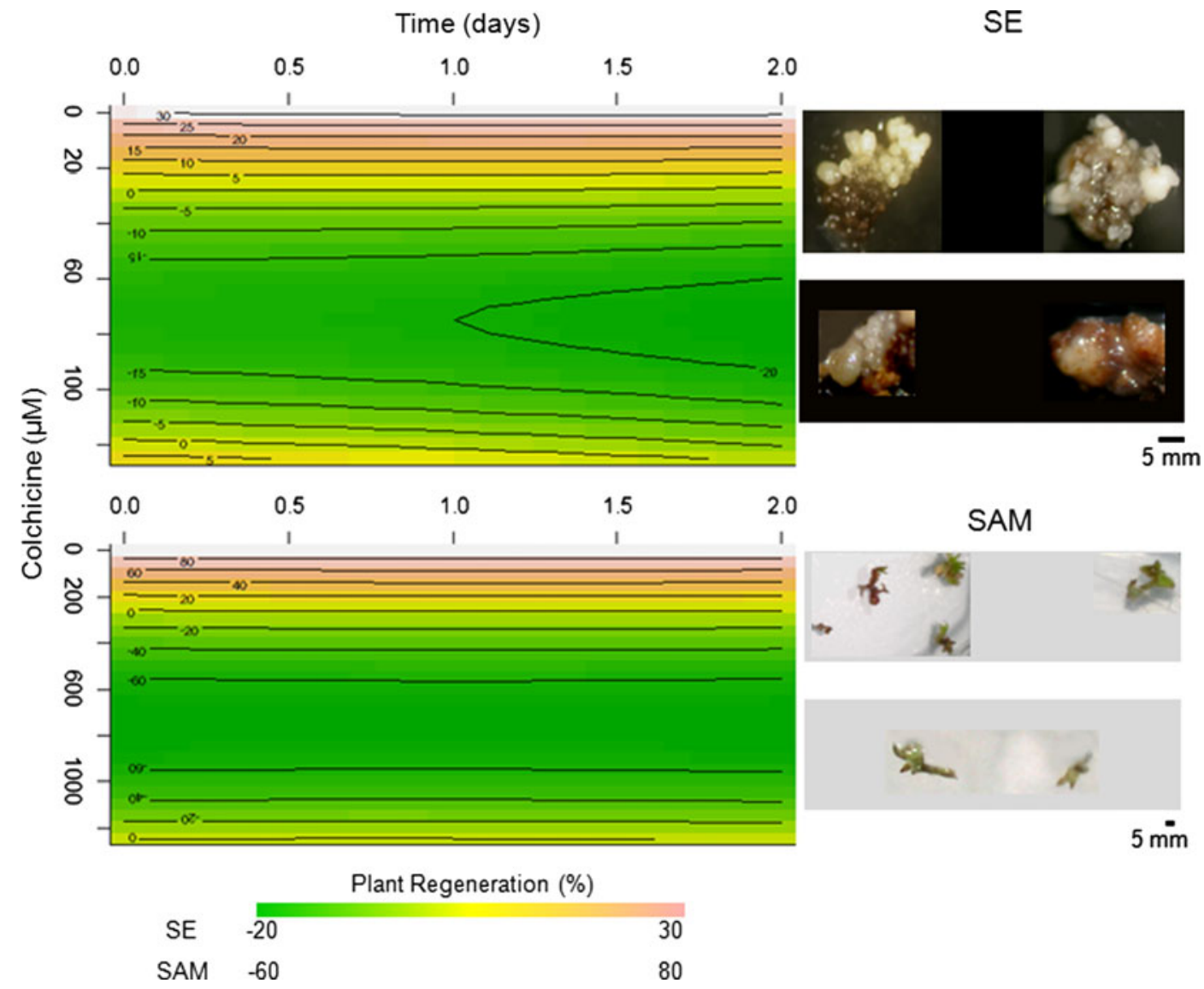

Fig. 3 Surface response contour plots of colchicine treatment effects on grapevine plant regeneration via somatic embryogenesis (SE) and shoot organogenesis (SAM). Percentage of plant recovery is represented by color scale and the contour

plant regeneration and its effect increases linearly in response to concentration, up to $100 \mu \mathrm{M}$ (Fig. 4; Table 2).

Genetic and morphological analyses of the autopolyploids

Structures of the abaxial epidermis were analyzed by light microscopy for ten randomly collected leaves from independent regenerants of each cultivar and light microscopy measurements of abaxial leaf epidermis structures compared to the ploidy level determined by cytological analyses (Table 3). Linear measures of stomata length and width and chloroplast density per guard cell area were positively correlated to chromosome number (Table 3; Fig. 5). Similarly, stomata density per area was negatively correlated to the ploidy level (Table 3; Fig. 5).

numbers. Contour lines represent significant points determined by least significant difference (LSD) at $P>0.01$. Representative explants are shown for lowest and highest response curves (right). (Color figure online)

Autotetraploid plants of 'BRS Clara' and 'Crimson Seedless' are morphologically similar to the original diploids, except for shorter internodes, thicker stems and more compact root systems, observed for in vitro propagated plants (Fig. 6).

\section{Discussion}

In vitro polyploidy induction has been successfully achieved for a wide range of plant species using several explants types, including; apical and lateral meristematic regions, callus, seeds, zygotic and somatic embryos (Dhooghe et al. 2011). The induction of plant morphogenesis from niches of stem cell in meristematic regions under tissue culture conditions favors uni- or oligocellular regeneration; thus, reducing the frequency of mixoploid chimeras, commonly 


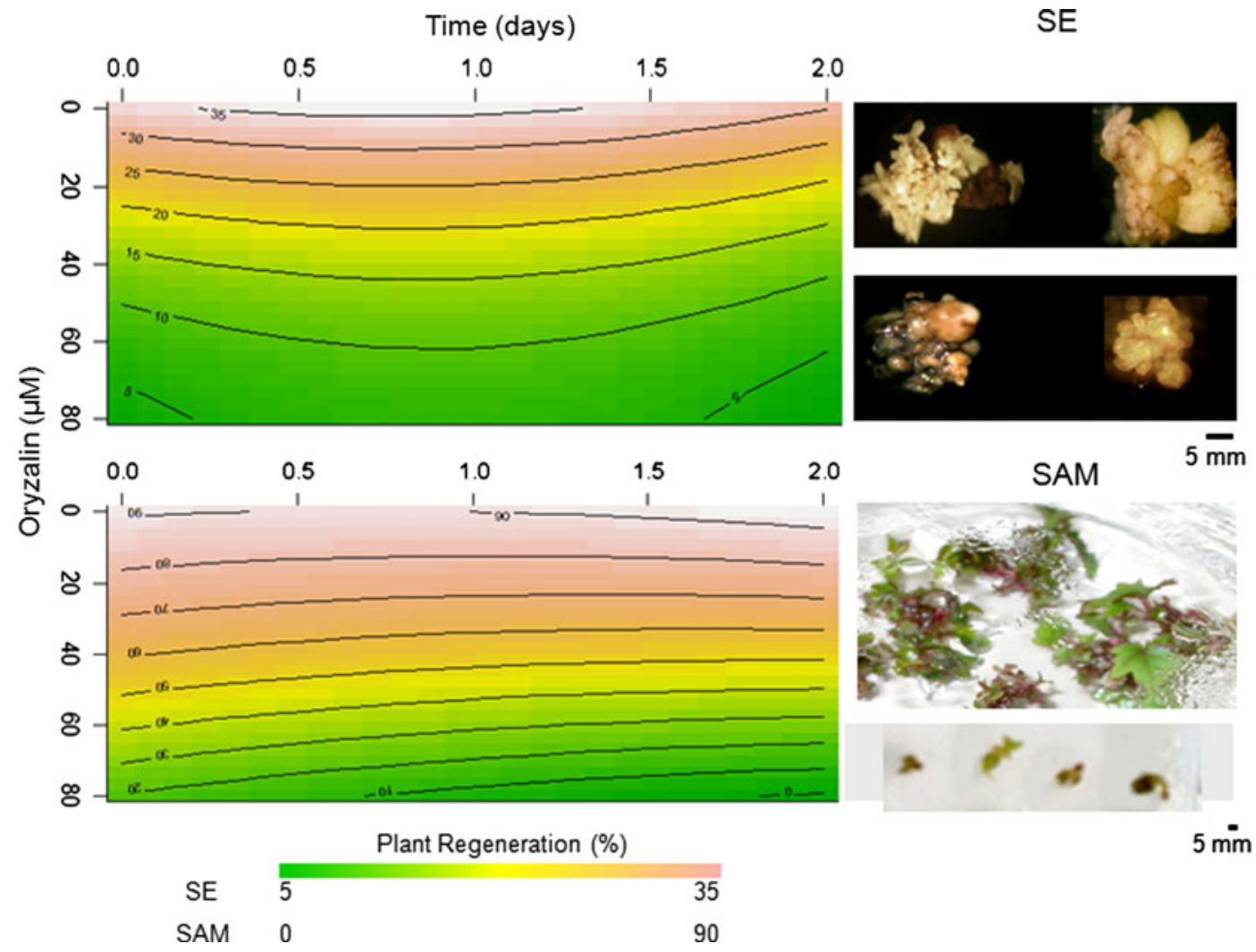

Fig. 4 Surface response contour plots of oryzalin treatment effects on grapevine plant regeneration via somatic embryogenesis (SE) and shoot organogenesis (SAM). Percentage of plant recovery is represented by color scale and the contour

numbers. Contour lines represent significant points determined by least significant difference (LSD) at $P>0.01$. Representative explants are shown for lowest and highest response curves (right). (Color figure online)

Table 1 Plant regeneration and polyploidy induction of somatic embryos and shoot apices of seedless grapes cultivars treated with colchicine for $48 \mathrm{~h}$ in the dark, in liquid media, at $20^{\circ} \mathrm{C}$

\begin{tabular}{|c|c|c|c|c|c|c|c|c|}
\hline \multirow[t]{2}{*}{ Cultivar } & \multirow[t]{2}{*}{ Explant type } & \multirow{2}{*}{$\begin{array}{l}\text { Colchicine } \\
(\mu \mathrm{M})\end{array}$} & \multicolumn{2}{|l|}{ Explants } & \multirow{2}{*}{$\begin{array}{l}\text { Regenerants } \\
\text { Analyzed } \\
(\%)\end{array}$} & \multicolumn{3}{|c|}{ Ploidy level } \\
\hline & & & Treated & $\begin{array}{l}\text { Regenerated } \\
(\%)\end{array}$ & & Diploid & Tetraploid & Aneuploid \\
\hline \multirow[t]{4}{*}{ BRS clara } & \multirow{2}{*}{$\begin{array}{l}\text { Somatic } \\
\text { embryos }\end{array}$} & 20 & 60 & $12(20.02) b$ & $10(83.33)$ & 7 & 3 & 0 \\
\hline & & 80 & 62 & $5(8.04) \mathrm{c}$ & $5(100.00)$ & 2 & 2 & 1 \\
\hline & \multirow[t]{2}{*}{ Shoot apices } & 250 & 60 & $17(28.33) \mathrm{a}$ & $10(58.82)$ & 7 & 3 & 0 \\
\hline & & 1,250 & 60 & $6(10.00) \mathrm{c}$ & $6(100.00)$ & 2 & 3 & 1 \\
\hline \multirow{4}{*}{$\begin{array}{l}\text { Crimson } \\
\text { seedless }\end{array}$} & \multirow{2}{*}{$\begin{array}{l}\text { Somatic } \\
\text { embryos }\end{array}$} & 20 & 65 & $9(13.84) b$ & $9(100.00)$ & 4 & 3 & 1 \\
\hline & & 80 & 60 & $3(5.03) \mathrm{d}$ & $3(100.00)$ & 1 & 2 & 0 \\
\hline & \multirow[t]{2}{*}{ Shoot apices } & 250 & 67 & $21(31.34) \mathrm{a}$ & $10(47.61)$ & 3 & 3 & 2 \\
\hline & & 1,250 & 60 & $6(10.00) c$ & $6(100.00)$ & 2 & 3 & 1 \\
\hline
\end{tabular}

The ploidy level was determined by chromosome counting from metaphase root cells. The results represent totals from three independent experiments. Statistical differences, calculated by Tukey Honestly Significant Difference at $P>0.01$, are represented by lower case letters 
Table 2 Plant regeneration and polyploidy induction of somatic embryos and shoot apices of seedless grapes cultivars treated with oryzalin for $48 \mathrm{~h}$ in the dark, in liquid media, at $20^{\circ} \mathrm{C}$

\begin{tabular}{|c|c|c|c|c|c|c|c|c|}
\hline \multirow[t]{2}{*}{ Cultivar } & \multirow[t]{2}{*}{ Explant type } & \multirow{2}{*}{$\begin{array}{l}\text { Oryzalin } \\
(\mu \mathrm{M})\end{array}$} & \multicolumn{2}{|c|}{ Explants } & \multirow{2}{*}{$\begin{array}{l}\text { Regenerants } \\
\text { Analyzed } \\
(\%)\end{array}$} & \multicolumn{3}{|c|}{ Ploidy level } \\
\hline & & & Treated & $\begin{array}{l}\text { Regenerated } \\
(\%)\end{array}$ & & Diploid & Tetraploid & Aneuploid \\
\hline \multirow[t]{4}{*}{ BRS clara } & \multirow{2}{*}{$\begin{array}{l}\text { Somatic } \\
\text { embryos }\end{array}$} & 20 & 60 & $17(28.33) b$ & $10(58.80)$ & 3 & 6 & 1 \\
\hline & & 40 & 57 & $12(12.05) \mathrm{b}$ & $10(83.33)$ & 4 & 6 & 0 \\
\hline & \multirow[t]{2}{*}{ Shoot apices } & 20 & 62 & $24(38.07) a$ & $10(41.67)$ & 7 & 3 & 0 \\
\hline & & 40 & 60 & $18(30.00) \mathrm{b}$ & $10(55.56)$ & 5 & 5 & 0 \\
\hline \multirow{4}{*}{$\begin{array}{l}\text { Crimson } \\
\text { seedless }\end{array}$} & \multirow{2}{*}{$\begin{array}{l}\text { Somatic } \\
\text { embryos }\end{array}$} & 20 & 60 & $5(8.33) \mathrm{d}$ & $5(100.00)$ & 2 & 3 & 0 \\
\hline & & 40 & 60 & $3(5.00) \mathrm{d}$ & $3(100.00)$ & 1 & 1 & 1 \\
\hline & \multirow[t]{2}{*}{ Shoot apices } & 20 & 64 & $28(43.75) a$ & $10(35.71)$ & 5 & 5 & 0 \\
\hline & & 40 & 62 & $18(29.03) b$ & $10(55.56)$ & 4 & 6 & 0 \\
\hline
\end{tabular}

The ploidy level was determined by chromosome counting from metaphase root cells. The results represent totals from three independent experiments. Statistical differences, calculated by Tukey Honestly Significant Difference at $P>0.01$, are represented by lower case letters

Table 3 Correlation coefficients between abaxial epidermis morphology and ploidy level in plants regenerated from somatic embryos and shoot apices treated with colchicine and oryzalin

\begin{tabular}{lllll}
\hline Cultivar & Ploidy level & \multicolumn{2}{l}{ Guard cell } & Stomata density $\left(\right.$ number per mm $\left.{ }^{-2}\right)$ \\
\cline { 2 - 4 } & & Length $(\mu \mathrm{m})$ & Width $(\mu \mathrm{m})$ & \\
\hline BRS clara & $2 n$ & $28.1 \pm 0.3$ & $19.2 \pm 0.5$ & $185.1 \pm 3.3$ \\
& $4 n$ & $34.5 \pm 0.7$ & $25.7 \pm 0.8$ & $157.9 \pm 2.5$ \\
Crimson seedless & $2 n$ & $22.5 \pm 0.6$ & $18.5 \pm 0.4$ & $175.7 \pm 3.6$ \\
& $4 n$ & $33.8 \pm 0.5$ & $24.5 \pm 0.7$ & $152.0 \pm 1.8$ \\
Correlation coefficient & - & $0.783^{* *}$ & $0.821^{* *}$ & $-0.650^{*}$ \\
\hline
\end{tabular}

The results correspond to mean measurements from fifteen stomata from five microscopic fields, visualized in ten independent leaves collected from five randomly selected wild-type $(2 n=38)$ and polyploid $(4 n=76)$ plants. The correlation coefficient between tetraploidy and the mean values of guard cell and stomata parameters is shown. Statistical significance is represented by $*$ and $* *$ at $P<0.01$ and $P<0.01$, respectively

obtained from the polyploidization of tissues that undergo multiple-cell regeneration (Dhooghe et al. 2011; Predieri 2001). In grapevine, the most effective regeneration systems, based on single or a few cells, include somatic embryogenesis (Martinelli and Gribaudo 2009) and shoot organogenesis (Dutt et al. 2008), and both were tested as explants for in vitro chromosome doubling.

Genotype is considered the determinant factor for somatic embryogenesis competence induction in grapevine (Martinelli and Gribaudo 2009), however, no significant differences were observed in competence induction, somatic embryo production and plant regeneration between 'BRS Clara' and 'Crimson Seedless' in the absence of antimitotic agents. The presence of common parentage in the genealogy of both seedless cultivars, such as 'Emperor' (Ramming et al. 1995; Camargo et al. 2003), may have contributed for the similar embryogenesis responses.

Regeneration from meristematic cells at the shoot apex is a widespread developmental program in plants and is less affected by genetic differences. In grapevine, it has been demonstrated to be effective for a wide range of genotypes, including hybrids and Vitis rotundifolia (Gray and Fisher 1985; Dutt et al. 2008). The lower frequencies of plant recovery from somatic embryos in comparison to shoot apices have been previously reported (Dutt et al. 2008; Martinelli and Gribaudo 2009) and are likely to be a consequence of the complex developmental changes necessary for embryogenesis competence induction, program establishment and plant regeneration (Marsoni et al. 2008; 

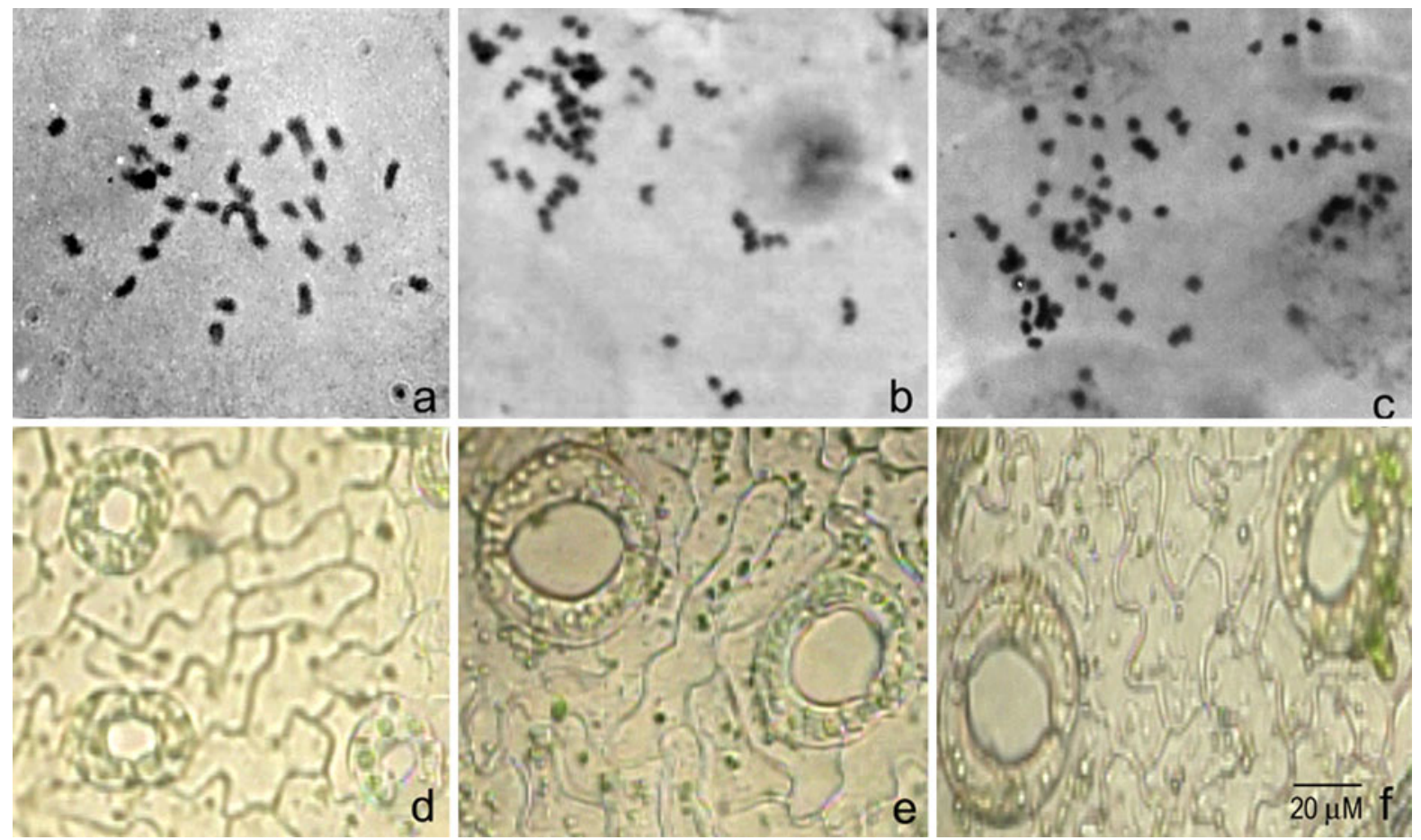

Fig. 5 Chromosome counts in root tip cells of wild-type $(2 n=2 x=38)$ 'BRS Clara' (a), and autotetraploid 'BRS Clara' $(2 n=4 x=76) \quad(\mathbf{b}), \quad$ and 'Crimson Seedless' $(2 n=4 x=76)(\mathbf{c})$, at $\times 1,000$ magnification. Light microscopy analysis of abaxial epidermal structures in wild-type 'BRS Clara' (d), and autotetraploid 'BRS Clara' (e), and 'Crimson Seedless' (f), at $\times 400$ magnification

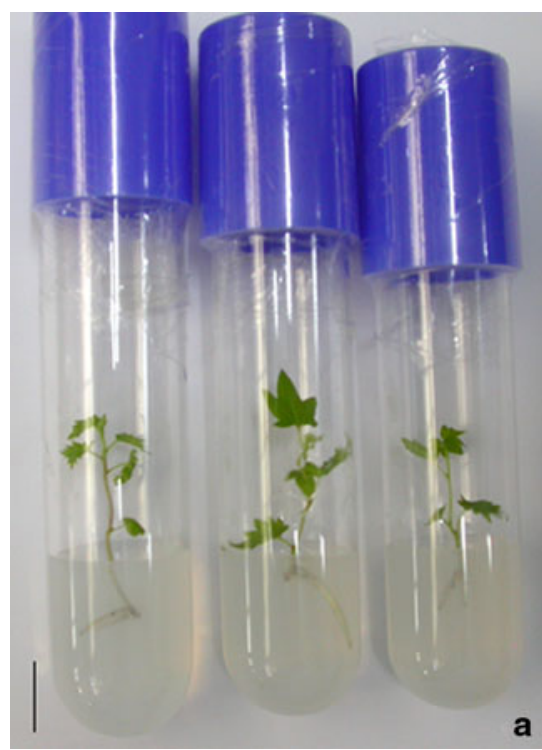

Fig. 6 In vitro grapevine wild-type and tetraploid plants of 'BRS Clara' and 'Crimson Seedless'. Forty-five day old wildtype (left) and colchicine induced polyploidy (right) 'BRS

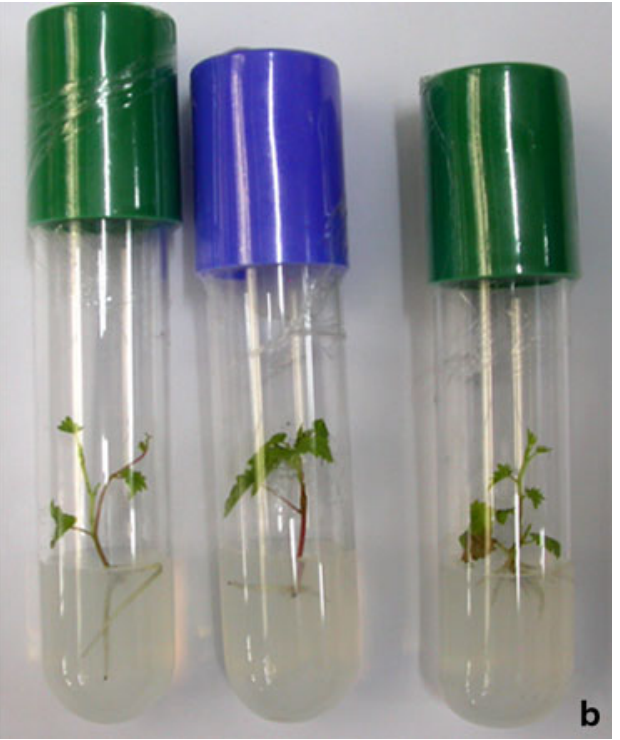

Clara' (a), and wild-type (left) and oryzalin induced polyploidy (right) 'Crimson Seedless' (b) 
Maillot et al. 2009; Gambino et al. 2011). In contrast, de novo shoot organogenesis from meristematic cells is dependent on reiterative development from axillary meristems, a process that does not require extensive cellular reprogramming due to the undifferentiated nature of the stem cells (Laux et al. 1996; DuClercq et al. 2011; Chatfield et al. 2013). Thus, the high efficiencies of shoot production from apices for both cultivars are a direct consequence of totipotent stem cells in the shoot meristem.

The differential plant regeneration response observed for colchicine and oryzalin treatments may be a consequence of their distinct mechanisms of action. Although both compounds interfere with the formation of the spindle apparatus during cell divisions via tubulin interactions, colchicine directly binds the Bsubunit of the protein preventing its polymerization, or at higher concentrations, promotes microtubule depolymerization (Caperta et al. 2006), whereas, oryzalin binds tubulin $\alpha$ subunit, via a conserved threonine residue (Thr239), and prevents microtubule polymerization (Anthony and Hussey 1999). In plants, oryzalin has been demonstrated to affect the morphology of the endoplasmic reticulum and Golgi apparatus by yet unknown mechanisms (Langhans et al. 2009). Similarly, pleiotroic effects of colchicine have also been described in animal (Koch and Spitzer 1982; Alberch and Gale 1983; Koch and Spitzer 1983; Poloz and O’Day 2012) and plant systems (Luckett 1989; Liu et al. 2009). Distinct biochemical properties of plant tubulin due to transcriptional regulation of gene families and post-transcriptional modifications have been associated to functional specificity in plants (Breviario et al. 2013). In grapevine, acidic isoforms of $\alpha$ and $\beta$-tubulin were preferentially found in buds, whereas more basic forms were present in structures of reproductive origin (flowers and tendrils) and leaves (Parrotta et al. 2010). Thus, the distinct tubulin composition of the microtubules from somatic embryos and shoot apices may also have contributed to the differential sensitivity to colchicine and oryzalin.

In Arabidopsis ecotypes, the sensitivity to colchicine has been demonstrated to be genetically controlled, however, it remains to be demonstrated whether it is associated to the control of uptake or detoxification processes (Yu et al. 2009). No effect of the genomic context was observed for the sensitivity of 'Crimson Seedless' and 'BRS Clara' to the employed antimicrotubule compounds.
The efficiencies of colchicine treatments for somatic embryo polyploidization of 'BRS Clara' and 'Crimson seedless' were higher than those reported for several grape cultivars (Notsuka et al. 2000; Motosugi et al. 2002; Wakana et al. 2005; Yang et al., 2006; Sarikani and Wakana 2009). In vivo colchicine treatment of several organs of Vitis genotypes have been reported to be even less effective in generating autopolyploids (Dermen 1954; Kuliev 2011). In addition to its cytotoxicity, a mutagen effect of colchicine has been reported for some plant species (Van Tuyl et al. 1992; Carvalho et al. 2005; Rêgo et al. 2011), although its direct action on plant DNA has never been conclusively demonstrated. Colchicine pleiotropic effects predicted by model fitting to higher order designs are represented by the almost four-fold increase in aneuploidy, in comparison to oryzalin, especially at higher concentrations of the antimitotic agent.

In vitro autopolyploidy induction was slightly more effective with oryzalin for the investigated seedless grape cultivars, as shown for other plant species (Chalak and Legave 1996; Vainola 2000; Carvalho et al. 2005). To our knowledge, it is the first report of in vitro induction of autopolyploid grapevine by oryzalin.

The recovery of autopolyploid, non-chimerical plants is dependent on the cellular lineage affected by the antimicrotubule compound; homogeneous polyploidy individuals are derived from the regeneration of a single cell or a small number of cells from sub-epidermal layers (L2 and L3) that give rise to the generative lineage (review in Besnard et al. 2011; DuClercq et al. 2011). In vitro techniques for plant regeneration via de novo organogenesis and somatic embryogenesis allow antimicrotubule compounds to access the inner cell layers of plant meristems and impair mitotic chromosome segregation in adult stem cells differentiating into novel organs. Thus, shoot apices and somatic embryos are suitable explants for ploidy level manipulations in grapevine. De novo organogenesis from the meristematic cells at shoot apices is advantageous, in comparison to somatic embryogenesis, due to its relative independence on the genotype, shorter regeneration time (Fig. S2) and higher rates of plant regeneration. The excision of leaf primordia and immersion in liquid medium supplemented with the polyploidization agent facilitates access of the compound to inner cell layers, reducing the frequency of ploidy chimerae. 
Several variables are involved in optimizing treatment of plant material with antimicrotubule agents to generate autopolyploids, including: explants type, cultivar, agent and its concentration, treatment time and regeneration pathway. Thus, extensive experimentation would be required to test the variables, their levels and interactions. Response modeling, based on finite experimental data, is a promising tool to help the identification of the critical factors and their influence for several in vitro methodologies, as recently shown for pear micropropagation (Reed et al. 2013; Wada et al. 2013).

The measurement of abaxial leaf epidermis structures is simple, fast, non-destructive and does not require expensive reagents or equipments. Stomata size was demonstrated to be a suitable predictor of genome size for induced autopolyploid grapevine, as shown for a wide range of angiosperms submitted to in vitro autopolyploidization (Carvalho et al. 2005; Yang et al. 2006; Rêgo et al. 2011). Recent studies have demonstrated that plants of wild potato species, polyploidized by in vitro oryzalin treatment, exhibited no consistent morphological feature, suggesting that the observed morpho-anatomical changes are stochastic (Aversano et al. 2013). Although the relationship between genome and stomata size and its biological significance in autopolyploids is debatable (Beaulieu et al. 2008; Hodgson et al. 2010; Parisod et al. 2010), the direct comparison between epidermal structures size and DNA content is useful for in vitro induced grapevine polyploids.

Similarly, shorter branches, larger stem diameters and smaller roots were described for autotetraploid plants from three Vitis rootstock cultivars, whereas, no morphological alteration was reported for allopolyploids (Motosugi et al. 2002). Berry size and sensory and functional compound contents were also increased in tetraploid grape cultivars, in comparison to diploid ones (Shiraishi et al. 2012, 2010, 2008). No significant increase in soluble solids and total sugar contents were observed in tetraploid grape berries (Shiraishi et al. 2012), in contrast to the higher levels of soluble solids observed for tetraploid passion fruit (Rêgo et al. 2011). In grapevine, these traits are highly influenced by the environment and exhibit low correlation to the genotype (Shiraishi et al. 2012).

In conclusion, the current work presents thorough optimization of the factors influencing in vitro induction of autopolyploidy in seedless grapes cultivars from shoot apices and somatic embryos, employing antimicrotubule agents; colchicine and oryzalin. The critical factors influencing plant regeneration were determined by response surface modeling and the novel insights on the effects of the compounds interfering with tubulin metabolism were provided. The established protocols allowed the recovery of non-chimerical autotetraploid plants at rates higher than $30 \%$ for both tested cultivars. Stomata size parameters were shown to correlate to DNA content in the regenerants and were effective for preliminary polyploidy screens. To our knowledge, it is the first report of in vitro oryzalin induced polyploidization of grapevine.

\section{References}

Alberch P, Gale EA (1983) Size dependence during the development of the amphibian foot. Colchicine-induced digital loss, reduction. J Emb Exp Morphol 76:177-197

Anthony RG, Hussey PJ (1999) Dinitroaniline herbicide resistance and the microtubule cytoskeleton. Trends Plant Sci 4:112-116. doi:10.1016/S1360-1385(99)01378-3

Arora PK, Jyot G, Singh B, Battu RS, Singh B, Aulakh PS (2009) Persistence of imidacloprid on grape leaves, grape berries and soil. Bull Environ Contam Toxicol 82:239-242. doi:10.1007/s00128-008-9554-y

Aversano R, Caruso I, Aronne G, De Micco V, Scognamiglio N, Carputo D (2013) Stochastic changes affect Solanum wild species following autopolyploidization. J Exp Bot 64: 625-635. doi:10.1093/jxb/ers357

Beaulieu JM, Leitch IJ, Patel S, Pendharkar A, Knight CA (2008) Genome size is a strong predictor of cell size and stomatal density in angiosperms. New Phytol 179: 975-986. doi:10.1111/j.1469-8137.2008.02528.x

Berenschot AS, Zucchi MI, Tulmann-Neto A, Quecini V (2008) Mutagenesis in Petunia $\times$ hybrida Vilm. and isolation of a novel morphological mutant. Braz J Plant Physiol 20: 95-103. doi:10.1590/S1677-04202008000200002

Bergamini C, Cardone MF, Anaclerio A, Perniola R, Pichierri A, Genghi R, Alba V, Forleo LR, Caputo AR, Montemurro C, Blanco A, Antonacci D (2013) Validation assay of VvAGL11 marker in a wide range of genetic background for early selection of stenospermocarpy in Vitis vinifera $\mathrm{L}$. Mol Biotechnol 54:1021-1030. doi:10.1007/s12033-0139654-8

Besnard F, Vernoux T, Hamant O (2011) Organogenesis from stem cells in planta: multiple feedback loops integrating molecular and mechanical signals. Cell Mol Life Sci 68:2885-2906. doi:10.1007/s00018-011-0732-4

Breviario D, Gianì S, Morello L (2013) Multiple tubulins: evolutionary aspects and biological implications. Plant J. doi:10.1111/tpj.12243

Cai X, Kang X-Y (2011) In vitro tetraploid induction from leaf explants of Populus pseudo-simonii Kitag. Plant Cell Rep 30:1771-1778. doi:10.1007/s00299-011-1085-z 
Camargo UA, Nachtigal JC, Maia JDG, Oliveira PRD, Protas JFS (2003) BRS Clara: nova cultivar de uva de mesa branca sem semente. Bento Gonçalves: Embrapa-CNPUV (Embrapa Uva e Vinho. Comunicado Técnico, 46), in Portuguese. http://www.cnpuv.embrapa.br/publica/comunicado/\#a2003. Accessed 10 May 2013

Caperta AD, Delgado M, Ressurreição F, Meister A, Jones RN, Viegas W, Houben A (2006) Colchicine-induced polyploidization depends on tubulin polymerization in c-metaphase cells. Protoplasma 227:147-153. doi:10. $1159 / 000151319$

Carvalho JFR, Carvalho CR, Otoni WC (2005) In vitro induction of polyploidy in annatto (Bixa orellana). Plant Cell Tiss Organ Cult 80:69-75. doi:10.1007/s11240-004-88335

Chalak L, Legave JM (1996) Oryzalin combined with adventitious regeneration for an efficient chromosomoe doubling of trihaploid kiwifruit. Plant Cell Rep 16:97-100. doi:10. 1007/BF01275459

Chatfield SP, Capron R, Severino A, Penttila PA, Alfred S, Nahal H, Provart NJ (2013) Incipient stem cell niche conversion in tissue culture: using a systems approach to probe early events in WUSCHEL-dependent conversion of lateral root primordia into shoot meristems. Plant J 73: 798-813. doi:10.1111/tpj.12085

Chen ZJ (2010) Molecular mechanisms of polyploidy and hybrid vigor. Trend Plant Sci 15:57-71. doi:10.1016/j. tplants.2009.12.003

Dermen H (1954) Colchiploidy in grapes. J Hered 45:159-172

Dhooghe E, Van Laere K, Eeckhaut T, Leus L, Van Huylenbroeck J (2011) Mitotic chromosome doubling of plant tissues in vitro. Plant Cell Tiss Organ Cult 104:359-373. doi:10.1007/s11240-010-9786-5

Dokoozlian N, Luvisi D, Moriyama M, Schrader P (1995) Cultural practices improve color, size of 'Crimson Seedless'. California Agric 49:36-40. doi:10.3733/ca.v049n02p36

Doyle JJ, Flagel LE, Paterson AH, Rapp RA, Soltis DE, Soltis PS, Wendel JF (2008) Evolutionary genetics of genome merger and doubling in plants. Annu Rev Genet 42: 443-461. doi:10.1146/annurev.genet.42

DuClercq J, Sangwan-Norreel B, Catterou M, Sangwan RS (2011) De novo shoot organogenesis: from art to science. Trends Plant Sci 16:597-606. doi:10.1016/j.tplants.2011. 08.004

Dutt M, Li ZT, Dhekney SA, Gray DJ (2008) Transgenic plants from shoot apical meristems of Vitis vinifera L. "Thompson Seedless" via Agrobacterium-mediated transformation. Plant Cell Rep 26:2101-2110. doi:10.1007/s00299007-0424-6

Franks T, Gang He D, Thomas MR (1998) Regeneration of transgenic shape Vitis vinifera L. sultana plants: genotypic and phenotypic analysis. Mol Breed 4:321-333. doi:10. 1023/A:1009673619456

Galzy R (1964) Technique de thermotherapie des viroses de la vigne. Ann Epiphyt 15:245-256

Gambino G, Minuto M, Boccacci P, Perrone I, Vallania R, Gribaudo I (2011) Characterization of expression dynamics of WOX homeodomain transcription factors during somatic embryogenesis in Vitis vinifera. J Exp Bot 62: 1089-1101. doi:10.1093/jxb/erq349
Gray DJ, Fisher LC (1985) In vitro shoot propagation of grape species, hybrids and cultivars. Proc Fla State Hort Soc 98:172-174

Gribaudo I, Gambino G, Vallania R (2004) Somatic embryogenesis from grapevine anthers: identification of the optimal developmental stage for collecting explants. Am J Enol Vitic 55:427-430

Häntzschel KR, Weber G (2010) Blockage of mitosis in maize root tips using colchicine-alternatives. Protoplasma 241:99-104. doi:10.1007/s00709-009-0103-2

Hodgson JG, Sharafi M, Jalili A, Díaz S, Montserrat-Martí G, Palmer C, Cerabolini B, Pierce S, Hamzehee B, Asri Y, Jamzad Z, Wilson P, Raven JA, Band SR, Basconcelo S, Bogard A, Carter G, Charles M, Castro-Díez P, Cornelissen JH, Funes G, Jones G, Khoshnevis M, Pérez-Harguindeguy N, Pérez-Rontomé MC, Shirvany FA, Vendramini F, Yazdani S, Abbas-Azimi R, Boustani S, Dehghan M, Guerrero-Campo J, Hynd A, Kowsary E, Kazemi-Saeed F, Siavash B, Villar-Salvador P, Craigie R, Naqinezhad A, Romo-Díez A, de Torres Espuny L, Simmons E (2010) Stomatal vs. genome size in angiosperms: the somatic tail wagging the genomic dog? Ann Bot 105:573-584. doi:10. 1093/aob/mcq011

Jürgens G, Mayer U, Torres Ruiz RA, Berleth T, Misera S (1991) Genetic analysis of pattern formation in Arabidopsis embryo. Dev Suppl 1:27-38

Kasha KJ (2005) Chromosome doubling and recovery of doubled haploid plants. Haploids in crop improvement II, vol 56. Springer, Berlin, pp 123-152

Koch EA, Spitzer RH (1982) Autoradiographic studies of protein, polysaccharide synthesis during vitellogenesis in Drosophila. Cell Tiss Res 224:315-333

Koch EA, Spitzer RH (1983) Multiple effects of colchicine on oogenesis in Drosophila, induced sterility, switch of potential oocyte to nurse-cell developmental pathway. Cell Tiss Res 228:21-32

Kuliev VM (2011) Induced autotetraploid grape mutants. Cytol Genet 45:163-169

Langhans M, Niemes S, Pimpl P, Robinson DG (2009) Oryzalin bodies: in addition to its anti-microtubule properties, the dinitroaniline herbicide oryzalin causes nodulation of the endoplasmic reticulum. Protoplasma 236:73-84. doi:10. 1007/s00709-009-0059-2

Laux T, Mayer KF, Berger J, Jurgens G (1996) The WUSCHEL gene is required for shoot and floral meristem integrity in Arabidopsis. Development 122:87-96

Lenth RV (2009) Response-surface methods in R using rsm. J Stat Soft 32:1-17. doi: http://www.jstatsoft.org/v32/i07/. Accessed 22 Aug 2013

Liu XZ, Lin H, Mo XY, Long T, Zhang HY (2009) Genetic variation in colchicine-treated regenerated plants of Eucalyptus globulus Labill. J Genet 88:345-348

López-Miranda S, Hernández-Sánchez P, Serrano-Martínez A, Hellín P, Fenoll J, Núñez-Delicado E (2011) Effect of ripening on protein content and enzymatic activity of crimson seedless table grape. Food Chem 127:481-486. doi:10.1016/j.foodchem.2011.01.027

Luckett D (1989) Colchicine mutagenesis is associated with substantial heritable variation in cotton. Euphytica 42: 177-182. doi:10.1007/BF00042630 
Maillot P, Lebel S, Schellenbaum P, Jacques A, Walter B (2009) Differential regulation of SERK, LEC1-like and pathogenesis-related genes during indirect secondary somatic embryogenesis in grapevine. Plant Physiol Biochem 47:743-752. doi:10.1016/j.plaphy.2009.03.016

Marsoni M, Bracale M, Espen L, Prinsi B, Negri AS, Vannini C (2008) Proteomic analysis of somatic embryogenesis in Vitis vinifera. Plant Cell Rep 27:347-356. doi:10.1007/ s00299-007-0438-0

Martinelli L, Gribaudo I (2009) Strategies for effective somatic embryogenesis in grapevine: an appraisal. In: AngelakisRoubelakis KA (ed) Grapevine molecular physiology \& biotechnology. Springer, Dordercht, pp 461-493. doi:10. 1007/978-90-481-2305-6_17

Motosugi H, Okudo K, Kataoka D, Naruo T (2002) Comparison of growth characteristics between diploid and colchicineinduced tetraploid grapevine rootstocks. J Jpn Soc Hort Sci 71:335-341

Nitsch JP, Pratt C, Nitsch C, Shaulis NJ (1960) Substances in concord and concord seedless grapes in relation to berry development. Am J Bot 47:566-576

Notsuka K, Tsuru T, Shiraishi M (2000) Induced polyploid grapes via in vitro chromosome doubling. J Jpn Soc Hortic Sci 69:543-551

Olmo HP (1952) Breeding tetraploid grapes. Proc Am Soc Hort Sci 59:285-290

Parisod C, Holderegger R, Brochmann C (2010) Evolutionary consequences of autopolyploidy. New Phytol 186:5-17. doi:10.1111/j.1469-8137.2009.03142.x

Parrotta L, Cai G, Cresti M (2010) Changes in the accumulation of alpha- and beta-tubulin during bud development in Vitis vinifera L. Planta 231:277-291. doi:10.1007/s00425-0091053-9

Poloz Y, O’Day DH (2012) Colchicine affects cell motility, pattern formation and stalk cell differentiation in Dictyostelium by altering calcium signaling. Differentiation 83:185-199. doi:10.1016/j.diff.2011.12.006

Predieri S (2001) Mutation induced and tissue culture in improving fruits. Plant Cell Tiss Org Cult 64:185-210. doi:10.1023/A:1010623203554

R Core Team (2012) R: A language and environment for statistical computing. R Foundation for Statistical Computing, Vienna, ISBN 3-900051-07-0. http://www.R-project. org/. Accessed 23 Aug 2013

Ramming DW, Tarailo R, Badr SA (1995) 'Crimson Seedless': a new late maturing, red seedless table grape. HortScience 30:1473-1474

Reed BM, Wada S, DeNoma J, Niedz RP (2013) Improving in vitro mineral nutrition for diverse pear germplasm. In Vitro Cell Dev Biol 49:343-355. doi:10.1007/s11627013-9504-1

Rêgo MM, Rêgo ER, Bruckner CH, Finger FL, Otoni WC (2011) In vitro induction of autotetraploids from diploid yellow passion fruit mediated by colchicine and oryzalin. Plant Cell Tiss Organ Cult 107:451-459. doi:10.1007/ s11240-011-9995-6
Sarikani H, Wakana A (2009) Effect of ploidy on parthenocarpy in grape cultivars. Acta Horticult 827:433-438. http://www. actahort.org/books/827/827_74.htm. Accessed 10 May 2013

Schneider CA, Rasband WS, Eliceiri KW (2012) NIH Image to ImageJ: 25 years of image analysis. Nat Methods 9: 671-675. doi:10.1038/nmeth.2089

Sharma D, Awasthi MD (2003) Behaviour of forchlorfenuron residues in grape, soil and water. Chemosphere 50: 589-594. doi:10.1016/S0045-6535(02)00619-7

Shiraishi M, Fujishima H, Chijiwa H (2008) Tetraploid sucroseaccumulating grapevines. Vitis 47:191-192

Shiraishi M, Fujishima H, Chijiwa H (2010) Evaluation of table grape genetic resources for sugar, organic acid, and amino acid composition of berries. Euphytica 174:1-13. doi:10. 1007/s10681-009-0084-4

Shiraishi M, Fujishima H, Chijiwa H, Muramoto K (2012) Estimates of genotypic and yearly variations on fruit quality and functional traits for tetraploid table grape breeding. Euphytica 185:243-251. doi:10.1007/s10681-011-0562-3

Stout AB (1936) Seedlessness in grapes. Technical Bulletin, N. 238. New York State Agricultural Experiment Station, Geneva

Sweetman C, Wong DC, Ford CM, Drew DP (2012) Transcriptome analysis at four developmental stages of grape berry (Vitis vinifera $\mathrm{cv}$. Shiraz) provides insights into regulated and coordinated gene expression. BMC Genomics 13:691. doi:10.1186/1471-2164-13-691

Vainola A (2000) Polyploidization and early screening of Rhododendron hybrids. Euphytica 112:239-244. doi:10. 1023/A: 1003994800440

Van Tuyl JM, Meijer B, Van Dien MP (1992) The use of oryzalin as an alternative for colchicines in vitro chromosome doubling of Lilium and Nerina. Acta Hortic 325:625-630

Wada S, Niedz RP, DeNoma J, Reed BM (2013) Mesos components $(\mathrm{CaCl} 2, \mathrm{MgSO} 4, \mathrm{KH} 2 \mathrm{PO} 4)$ are critical for improving pear micropropagation. In Vitro Cell Dev Biol Plant 49:356-365. doi:10.1007/s11627-013-9508-x

Wakana A, Park SM, Hiramatsu M, Iianada N, Fukudome I, Yasukochi K (2005) Characteristics of seedless berries of tetraploid hybrid grapes (Vitis complex) from reciprocal crosses between diploid 'Muscat Bailey A' and tetraploid 'Red Pearl'. J Fac Agr Kyushu Uni 50:49-59

Xue J, Wang S, You X, Dong J, Han L, Liu F (2011) Multi-residue determination of plant growth regulators in apples and tomatoes by liquid chromatography/tandem mass spectrometry. Rapid Commun Mass Spectrom 25:3289-3297. doi:10.1002/rcm.5225

Yang XM, Cao ZY, An LZ, Wang YM, Fang XW (2006) In vitro tetraploid induction via colchicine treatment from diploid somatic embryos in grapevine (Vitis vinifera L.). Euphytica 152:217-224. doi:10.1007/s10681-006-9203-7

Yu Z, Haage K, Streit VE, Gierl A, Torres-Ruiz RA (2009) A large number of tetraploid Arabidopsis thaliana lines, generated by a rapid strategy, reveal high stability of neotetraploids during consecutive generations. Theor App Gen 118:1107-1119. doi:10.1007/s00122-009-0966-9 